\title{
PRIMEIRA DESCRIÇÃO DA ATIVIDADE PREDATÓRIA DE MACROBRACHIUM \\ PANTANALENSE, MACROBRACHIUM AMAZONICUM, MACROBRACHIUM BRASILIENSE E TRICHODACTYLUS PETROPOLITANUS CONTRA LARVAS DE AEDES AEGYPTI, ANOPHELES DARLING E CULEX QUINQUEFASCIATUS
}

Willian Marinho Dourado Coelho, Wilma Aparecida Starke Buzetti.

Universidade Estadual Paulista Júlio De Mesquita Filho - UNESP, Faculdade De Engenharia De Ilha Solteira. Ilha Solteira, SP.

\section{RESUMO}

Os culicídeos atuam na transmissão de sérias doenças aos seres humanos. O objetivo desse estudo é relatar pela primeira vez a atividade predatória de Macrobrachium pantanalense, Macrobrachium amazonicum, Macrobrachium brasiliense e Trichodactylus petropolitanus contra larvas de Aedes aegypti, Anopheles darling e Culex quinquefasciatus. As larvas foram colocadas em aquários com camarões e caranguejos, sendo a atividade predatória avaliada por meio de inspeção visual durante 24 horas. Foi observado que $100 \%$ das larvas foram consumidas em até dois minutos. Um fato inédito relatado nesse estudo foi a predação das larvas dos mosquitos $A$. aegypti, An. darling e C. quinquefasciatus por caranguejos da espécie T. petropolitanus. Estas mesmas espécies de crustáceos foram soltos em corpos d'água onde existem larvas desses insetos. Em apenas 48 horas houve eliminação total da população de larvas nesses locais. Houve acentuada redução na captura de mosquitos adultos pelas armadilhas instaladas nos locais de criadouros, ficando demonstrado que nas áreas onde os crustáceos foram liberados, a atividade predatória contra as larvas dos mosquitos foi suficiente para reduzir o número dos insetos adultos $p \leq 0,05$. Concluimos que esta é a primeira descrição da atividade predatória de $M$. pantanalense, M. amazonicum, M. brasiliense e $T$. petropolitanus contra larvas de A. aegypti, An. darlingi e $C$. quinquefasciatus, constituindo assim uma importante ferramenta no controle biológico desses parasitos-vetores.

Palavras-chave: Anopheles sp., Chikungunya, Dengue, Malaria, Vectors, Zika vírus

\section{FIRST DESCRIPTION OF PREDATORY ACTIVITY OF MACROBRACHIUM PANTANALENSE, MACROBRACHIUM AMAZONICUM, MACROBRACHIUM BRASILIENSE AND TRICHODACTYLUS PETROPOLITANUS ON AEDES AEGYPTI, ANOPHELES DARLING AND CULEX QUINQUEFASCIATUS LARVAE}

\begin{abstract}
The culicides acts in transmission of serious diseases to humans. The objective of this study was to report the predatory activity of Macrobrachium pantanalense, Macrobrachium amazonicum, Macrobrachium brasiliense and Trichodactylus petropolitanus on Aedes aegypti, Anopheles darling and Culex quinquefasciatus larvae. These larvae were placed in aquarium with shrimps, crabs and, the predatory activity was evaluated by visual inspection for 24 hours. Was observed that $100 \%$ of the larvae were consumed within two minutes. An unprecedented event reported in this study was the observation of predation of the larvae of A. aegypti, An. darling and C. quinquefasciatus for crabs of species $T$. petropolitanus. These same species of crustaceans were released in water bodies with the presence of larvae of these insects. In just 48 hours where not collected new larvae in the release sites of shrimps and crabs. The incidence of mosquitoes adults caught in traps
\end{abstract}


have marked reduction, allowing to infer that, in places where the crustaceans were released, the predatory activity on the larvae of mosquitoes was sufficient to reduce the number of adult mosquitoes $p \leq 0,05$. We concluded that this is the first description of the predatory activity of $M$. pantanalense, M. amazonicum, M. brasiliense and T. petropolitanus on A. aegypti, An. darling and C. quinquefasciatus larvae, constituting an important tool of biological control of these parasitesvectors.

Keywords: Anopheles sp., Chikungunya, Dengue, Malaria, Vectors, Zika virus

\section{INTRODUCTION}

A. aegypti is an important anthropophilic parasite, being considered as dengue vector (TAUIL, 2001), yellow fever (BRAGA \& VALLE, 2007), Zika virus (VASCONCELOS, 2015) and Chikungunya fever (DONALISIO \& FREITAS, 2015). Similarly the $C$. quinquefasciatus has been incriminated as a vector of important filariasis ${ }^{(5)}$ and viral infections (ELIZONDO-QUIROGA et al., 2005; NITATPATTANA et al., 2005; DIAS et al., 2006).

Many studies have been conducted in order to combat the proliferation of these insects, including biological control, such as the introduction of fish $\left({ }^{9,10}\right.$ and crustaceans ${ }^{11,12 .}$.

The objective of this study was to report the predatory activity of Macrobrachium pantanalense, Macrobrachium amazonicum, Macrobrachium brasiliense and Trichodactylus petropolitanus on Aedes aegypti, An. darling and Culex quinquefasciatus larvae.

\section{MATERIAL AND METHODS}

Larvae of the $A$. aegypti, An. darling and $C$. quinquefasciatus were collected in the environment of the Andradina city, São Paulo State $\left(20.8961^{\circ}, 51.37944^{\circ}\right.$ ), at $405 \mathrm{~m}$ altitude (Figure 1). The larvae were identified according to the taxonomic keys. The larvae were collected and aliquoted into groups of 80 each. These larvae were placed in rectangular aquarium of 30 liters with five shrimps of the species $M$. pantanalense, five $M$. amazonicum and five $M$. brasiliense (Figure 2). Before the introduction of the larvae in tanks, was made 12-hour fast with the shrimp species. Light traps and carbon dioxide traps remained installed close to the mosquitoes breeding sites three seven days before and seven days after the release of the shrimps and crabs. The number of adults was quantified to evaluate the reduction in the population of vectors.

\section{RESULTS}

The predatory activity was evaluated by visual inspection for 24 hours and was observed that $100 \%$ of the larvae were consumed within two minutes. Other three groups were formed with 20 shrimps each, separated by size (small, medium and large). The medium and large size shrimp consumed 80 larvae in 50 seconds. The small shrimps needed five minutes to consume $100 \%$ of the larvae. These aquariums also contained some crabs of species $T$. petropolitanus that were caught along with shrimps. Surprisingly, was observed that these crabs also fed the larvae that remained immobilized on the tank bottom or adhered to aquatic plants (Figure 3). These same species of crustaceans were released in water bodies and in water tanks in the environment with the presence of larvae of these insects (Figure 4). In just 48 hours where not collected new larvae in places where shrimps and crabs were released.

The reduction in the capture of adult stages of these parasites was statistically significant $p \leq 0,05$ (Table 1).

During the realization of this stage of the study there were no rains registered in the local release of crustaceans. 


\section{DISCUSSION}

In our study we determined the predatory activity of three different species of shrimps from the Tietê and Paraná rivers in the state of São Paulo, Brazil , in aquariums simulating the natural habitat of these crustaceans and also directly into the environment. Similarly, Rojas-Sahagún et al. (2012) found satisfactory predatory activity of Macrobrachium tenellum on larvae of $A$. aegypti in laboratory conditions, in México. These authors report that these animals are not aggressive and supports wide range of oxygen concentration. These data differ from ours because the species $M$. pantanalense and $M$. amazonicum and $M$. brasiliense found in this region are extremely aggressive, able to attack people entering in the water, and do not support well water with low oxygen.

This is also the first description of predation of crabs T. petropolitanus on larvae of A. aegypti, An. darling and $C$. quinquefasciatus. However, it is important that these animals only fed the larvae were temporarily immobilized in the tank bottom or adhered to aquatic vegetation.

The incidence of mosquitoes adults caught in traps have marked reduction, allowing to infer that, in places where the crustaceans were released, the predatory activity on the larvae of mosquitoes was sufficient to reduce the number of adult mosquitoes. An important observation to be made is that in Paraná and Tiete rivers, which have that have large populations of shrimp and crabs, is not observed presence of these and other dipterous larvae during the collections along rivers.

Cases of Zika virus and microcephaly are concentrated in the northeast of Brazil. It is important to remember that water scarcity in the region, the extensive use of water reservoirs, the precarious sanitation services and disability in stormwater runoff make the favorable scenario for maintaining high density of $A$. aegypti. Our results demonstrate that the release of these shrimps can provide the elimination of these and other larvae in these reservoirs within hours, eliminating the necessity of use of pesticides in drinking water destined for human, whose impact on people's health have not been properly established.

\section{CONCLUSIONS}

We concluded that $M$. pantanalense, $M$. amazonicum, $M$. brasiliense and $T$. petropolitanus are predators of $A$. aegypti, An. darling and $C$. quinquefasciatus larvae, able to consume large quantities of larvae in a short time, constituting an important tool of biological control of these parasites-vectors.

\section{REFERENCES}

Tauil PL. Urbanização e ecologia da dengue. Cad Saúde Pública 2001; 17: 99-102. https://doi.org/10.1590/S0102-311X2001000700018

Braga IA, Valle D. Aedes aegypti: inseticidas, mecanismo de ação e resistência. Epidemiol Serv Saúde 2007; 16: 279-93. https://doi.org/10.5123/s1679-49742007000400006

Vasconcelos PFC. Doença pelo vírus Zika: um novo problema emergente nas Américas? Rev PanAmazônica Saúde 2015; 6: 9-10. https://doi.org/10.5123/S2176-62232015000200001

Donalisio, MR, Freitas ARR. Chikungunya no Brasil: um desafio emergente. Rev Bras Epidemiol 2015; 18: 283-85. https://doi.org/10.1590/1980-5497201500010022

Medeiros Z, Menezes JA, Cesse EP, Lessa F. Control of linphatic filariais in Brazil. Epidemiol. Serv. Saúde $2003 ; 12$ : 77-86. 
Elizondo-Quiroga, D, Davis, CT, Fernandez-Salas I, Escobar-Lopez R, Velasco Olmos D, Soto Gastalum LC, et al. West Nile vírus isolation in humans and mosquitoes, Mexico. Emerg Infect Dis 2005; 11: 1449-52. https://doi.org/10.3201/eid1109.050121

Nitatpattana N, Apiwathnasorn C, Barbazan P, Leemingsawat S, Yoksan S, Gonzalez JP. First isolation of Japanese encephalitis from Culex quinquefasciatus in Thailand. South Asi J Trop Med and Public Health 2005; 36: 875-78.

Dias LA, Ré V, Almirón WR, Farías A, Vázquez A, Sanchez-Seco MP, et al. Genotype III Saint Louis Encephalitis Virus Outbreak, Argentina, 2005. Emerg Infect Dis 2006; 12.

Cavalcanti LPG, Lima WO, Cunha JCL, Santan EWP. Avaliação do impacto na infestação por Aedes aegypti em tanques de cimento do município de Canindé, Ceará, Brasil, após a utilização do peixe Betta splendens como alternativa de controle biológico. Rev Soc Bras Med Trop 2004; 37: 400-04. https://doi.org/10.1590/S0037-86822004000500006

Cavalcanti LPG, Pontes RJS, Regazzi ACF, Júnior FJP, Frutuoso RL, et al. Competência de peixes como predadores de larvas de Aedes aegypti, em condições de laboratório. Rev Saúde Pública 2007; 41: 16. https://doi.org/10.1590/S0034-89102006005000041

Collins AP. Laboratory evaluation of the freshwater prawn, Macrobrachium borellii, as a predator of mosquito larvae. Aquatic Sci 1998; 60: 22-7. https://doi.org/10.1007/pl00001312

Rojas-Sahagún CC, Hernández-Sánchez JM, Vargas-Ceballos MA, Ruiz-González LE, EspinosaChaurand LD, et al. Rev Cubana Med Trop 2012; 64: 15-323.

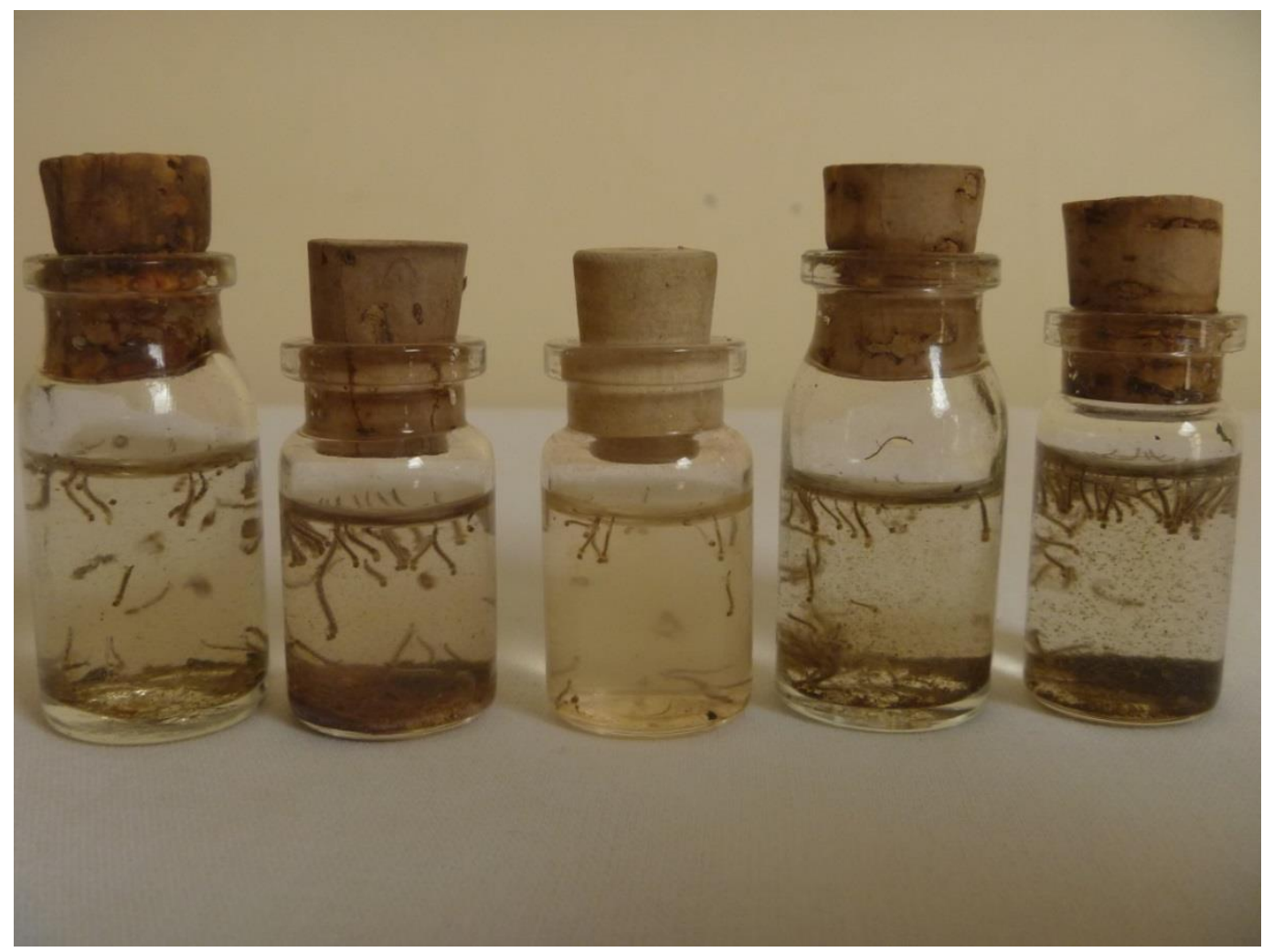

Figure 01. Larvae of A. aegypti, An. darling and C. quinquefasciatus captured in the peri-urban area of the city of Andradina, São Paulo, Brazil. 2016. 


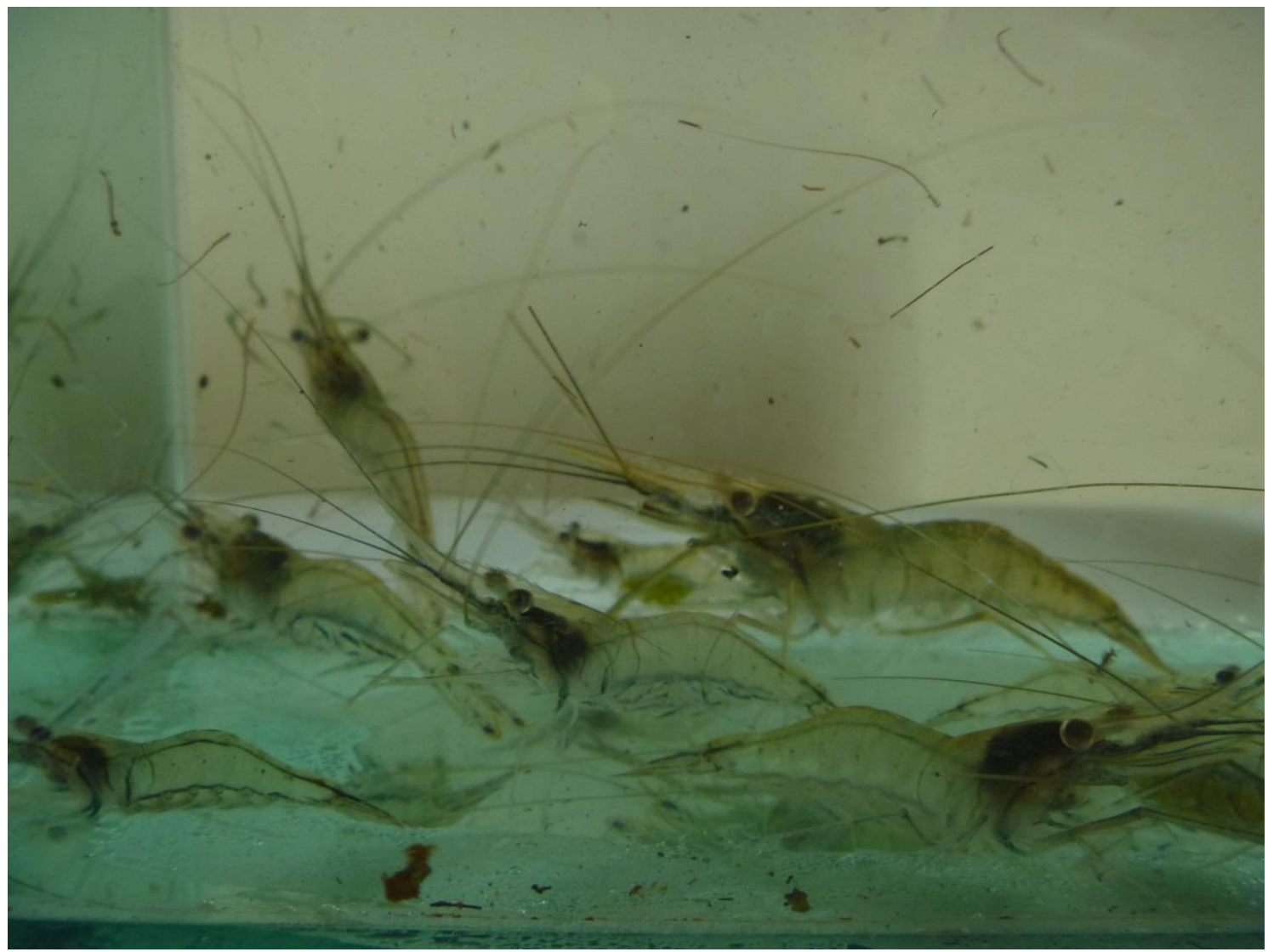

Figure 02. Shrimps used in the study. 2016.

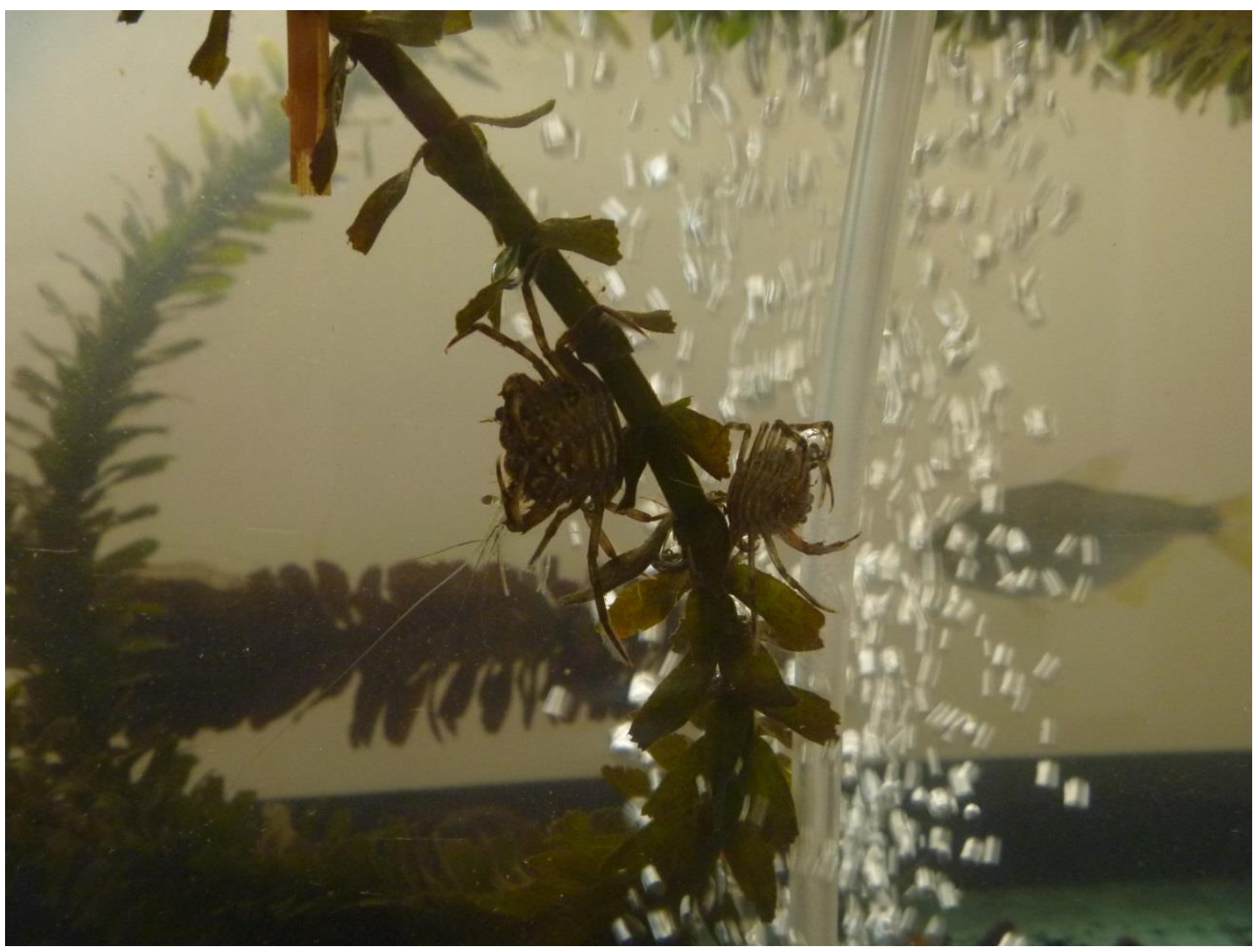

Figure 03. Crab (left) capturing and feeding larvae of An. darlingi released in aquarium. 2016. 


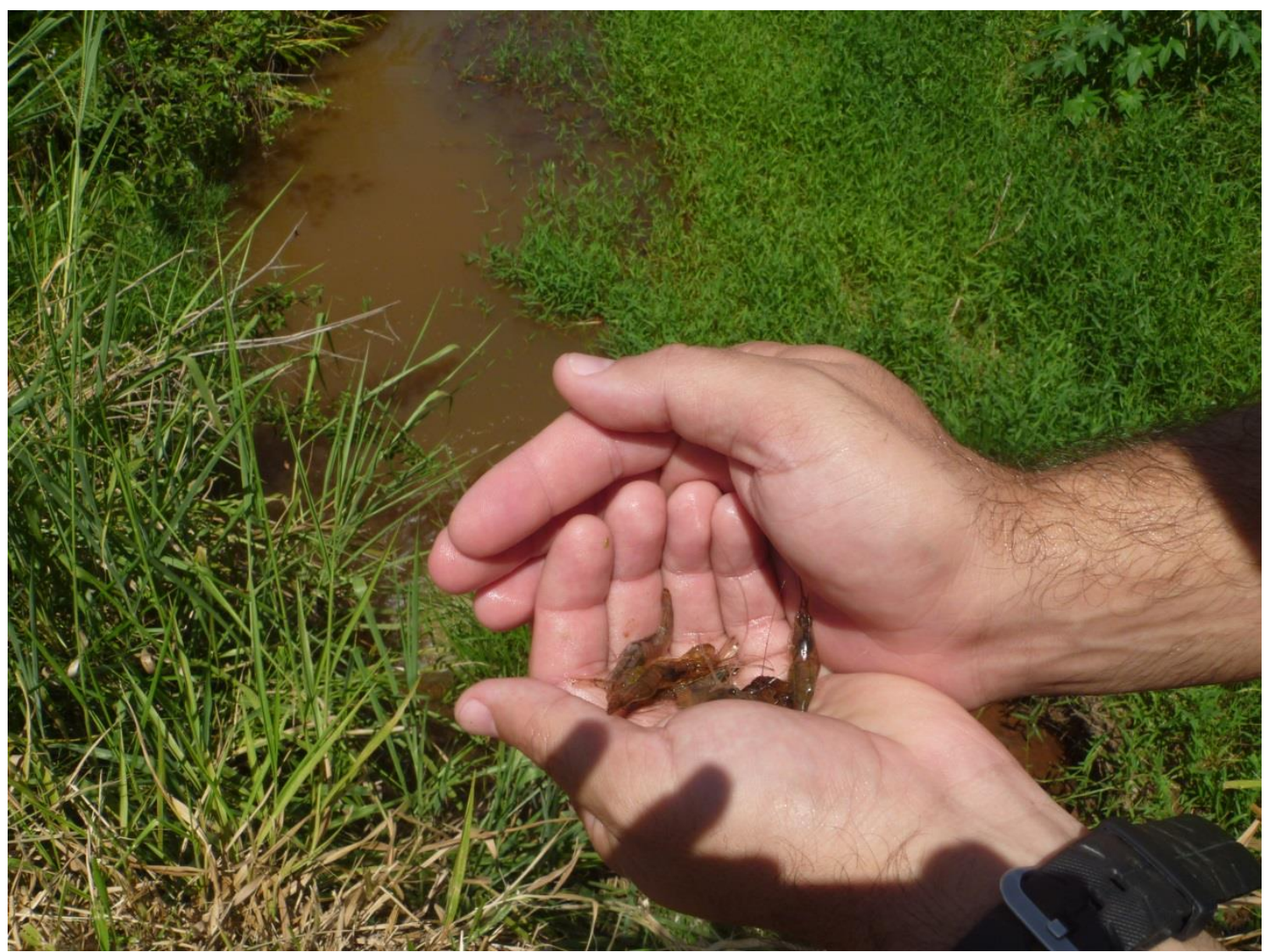

Figure 04. Release of shrimp in the environment, in area with breeding of mosquitoes. 2016. 